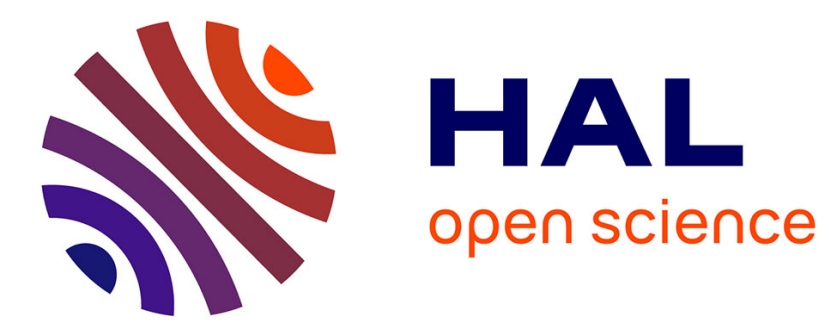

\title{
Genetic evidence for the origin of the agrimi goat (Capra aegagrus cretica)
}

Gila Kahila Bar-Gal, Patricia Smith, Eitan Tchernov, Charles Greenblatt, Pierre Ducos, Armelle Gardeisen, Liora Kolska Horwitz

\section{To cite this version:}

Gila Kahila Bar-Gal, Patricia Smith, Eitan Tchernov, Charles Greenblatt, Pierre Ducos, et al.. Genetic evidence for the origin of the agrimi goat (Capra aegagrus cretica). Journal of zoology, 2002, 256, pp.369-377. 10.1017/S0952836902000407 . hal-01415545

\section{HAL Id: hal-01415545 \\ https://hal.science/hal-01415545}

Submitted on 14 Dec 2016

HAL is a multi-disciplinary open access archive for the deposit and dissemination of scientific research documents, whether they are published or not. The documents may come from teaching and research institutions in France or abroad, or from public or private research centers.
L'archive ouverte pluridisciplinaire HAL, est destinée au dépôt et à la diffusion de documents scientifiques de niveau recherche, publiés ou non, émanant des établissements d'enseignement et de recherche français ou étrangers, des laboratoires publics ou privés. 


\title{
Genetic evidence for the origin of the agrimi goat (Capra aegagrus cretica)
}

Gila Kahila Bar-Gal ${ }^{1}$, Patricia Smith ${ }^{2}$, Eitan Tchernov ${ }^{3}$, Charles Greenblatt ${ }^{4}$, Pierre Ducos ${ }^{3}$, Armelle Gardeisen $^{5}$ and Liora Kolska Horwitz ${ }^{3 *}$

${ }^{1}$ Laboratory of Genomic Diversity, National Cancer Institute, Frederick 21702-1201, MD, U.S.A.

${ }^{2}$ Laboratory of Bioanthropology and Ancient DNA, Department of Anatomy and Embryology, The Hebrew University, Hadassah Medical School, P.O. Box 12272, Jerusalem 91120, Israel

${ }^{3}$ Department of Evolution, Systematics and Ecology, Faculty of Life Sciences, The Hebrew University of Jerusalem, Jerusalem 91904, Israel

${ }^{4}$ Kuvin Center for the Study of Infectious and Tropical Diseases, The Hebrew University, Hadassah Medical School, P.O. Box 12272,

Jerusalem 91120, Israel

${ }^{5}$ CNRS-UMR 154, CDAR, 390 Route de Perols, F-34 970, Lattes, France

(Accepted 7 March 2001)

\begin{abstract}
The agrimi goat Capra aegagrus cretica is unique to Crete and its offshore islands. It has been identified as a sub-species of the wild bezoar goat Capra aegagrus aegagrus Erxleben, 1777, which it closely resembles in horn shape, body form and coloration. This classification has been disputed by some researchers who claim that the agrimi are feral goats, derived from early domestic stock brought to the island by the first Neolithic settlers. In order to clarify this issue, DNA analyses (cytochrome $b$ and D loop sequences) were carried out on tissue of live and skeletonized agrimi and compared to sequences of wild and domestic caprines. Results conclusively show the agrimi to be a feral animal, that clades with domestic goats (Capra hircus) rather than with wild Asiatic bezoar. This study demonstrates that morphometric criteria do not necessarily reflect genetic affinities, and that the taxonomic classification of agrimi should be revised.
\end{abstract}

Key words: agrimi, Capra aegagrus cretica, bezoar goat, Capra aegagrus aegagrus, Crete, aDNA, cytochrome $b$

\section{INTRODUCTION}

The agrimi goat Capra aegagrus cretica is unique to Crete and its offshore islands. It has been identified by numerous researchers (Zimmerman et al., 1942-49; Harris, 1960-61; Schultze-Westrum, 1963; Epstein, 1971; Walker, 1983; Mason, 1984; Valdez, 1990; Harrison \& Bates, 1991) as a subspecies of the wild Asiatic bezoar goat (Capra aegagrus aegagrus Erxleben, 1777) which it resembles in horn shape and body form (Fig. 1), but it differs from the bezoar goat in being lighter coloured with broader markings and in having a shorter withers height (Mason, 1984; Porter, 1996).

Other researchers (Papageorgiou, 1974; Corbet, 1978; Groves, 1989; Ciani \& Masseti, 1991) have argued that the agrimi is probably feral, derived from domestic goats brought to the island by the first Cretan settlers in the Aceramic Neolithic period (c. 7000 uncal. BC). This is assumed because agrimi are absent from the Pleistocene fauna of Crete (Lax \& Strasser, 1992;

*All correspondence to: L. K. Horwitz
Jarman, 1996). The earliest identification of skeletal remains of agrimi, from the sites of Phaestos and Knossos (Jarman, 1996; Porter, 1996; Wilkens, 1996), date to the Late Neolithic period (c. 6000 uncal. BC) such that the timing of their first appearance clearly post-dates the arrival of domestic caprines on the island. Archaeozoological data (Jarman, 1996; Wilkens, 1996; Nobis, 1998), and literary, historical and pictorial evidence (Porter, 1996; Vanschoonwinkel, 1996), document that agrimi have been hunted on Crete from the Late Neolithic period through to the twentieth century.

Today agrimi herds are restricted to Samaria Gorge in the White Mountains, Western Crete (numbering some 500 animals in 1996), and three off-shore islands: Theodorou (c. 70 animals in 1996), Dia (c. 300 animals) and Agli Pandes (c. 90 animals) (Papageorgiou, 1974; Husband, 1977; Porter, 1996) (Fig. 2).

As standard archaeological and zoological methods have failed to resolve the question of the taxonomic status of agrimi, we have applied DNA analysis (cytochrome $b$ and D loop sequences) to establish the genetic affinity of the agrimi. 


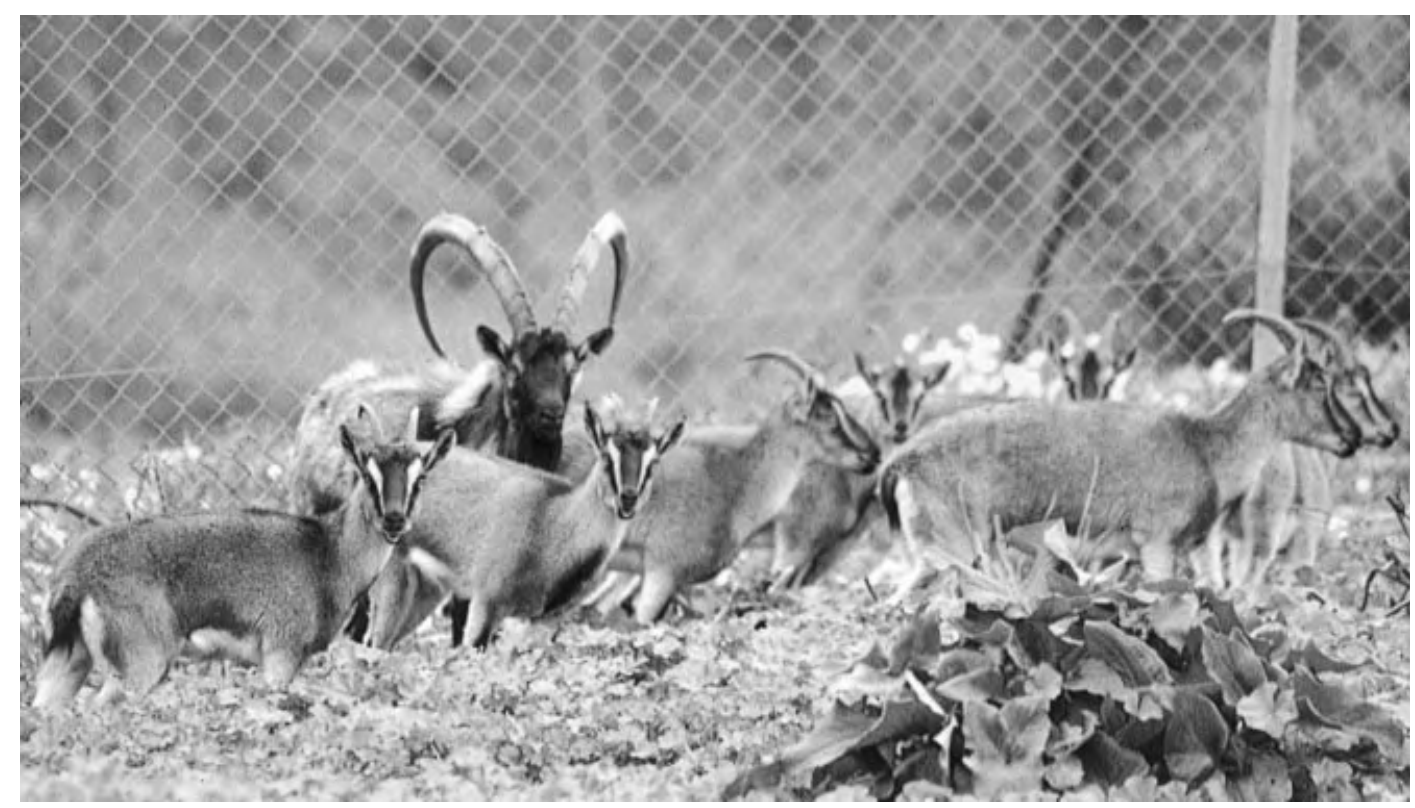

Fig. 1. Captive agrimi Capra aegagrus agrimi at the Hai-Bar Nature Reserve, Mount Carmel, northern Israel. Note the resemblance to the bezoar goat Capra aegagrus aegagrus in coat type, horn form and body proportions.

\section{MATERIALS AND METHODS}

DNA analyses were carried out on a total of 17 animals derived from 3 recently separated agrimi populations; a population living in Samaria Gorge, western Crete; a herd kept on Theodorou Island off Crete; and a captive herd held in Israel (Fig. 2a, b).

The population in Samaria Gorge, the last refuge for agrimi on the mainland of Crete, is the parent population of all the agrimi studied here. It is a free-living population and represents the remnants of the original agrimi population that was probably more widespread on the island. In 1928, 1937 and 1945, 1 breeding pair of agrimi were taken from the Samaria population and introduced into a reserve on Theodorou Island (Fig. 2b) (Schultze-Westrum, 1963; Papageorgiou, 1974; Husband \& Davis, 1984; Nicholson \& Husband, 1992). In 1975, as part of a programme to save endangered species and to re-introduce wildlife that had once inhabited the region, 6 agrimi were brought to Israel from Theodorou Island and held in captivity in the Hai-Bar Reserve on Mount Carmel (Fig. 2a) (Yoffe, 1980). In 1993, this herd numbered c. 55 goats.

For this study, blood samples were taken from 5 HaiBar reserve agrimi (while tranquillized) using a 3-ml tube containing $7.5 \%$ EDTA to prevent clotting. DNA was extracted from the blood using a method of isolation of DNA from peripheral blood (Filon et al., 1992). The DNA was amplified in a volume of $50 \mu 1$ through 25 cycles. For all PCR positive reactions, DNA was purified using the Boringer DNA purification kit. All the samples, purified and cored bands, were sequenced by the direct sequencing reaction using the Termo Sequenase kit (Amersham, U.K.).

In 1996, DNA samples were obtained from 5 skeletons of agrimi from Samaria Gorge, Western Crete and 7 skeletons from Theodorou Island. This enabled comparison of the Hai-Bar sample with its parent stock. In all instances, the Cretan agrimi skeletons were collected in the field and represent goats that had lived in the wild and are assumed to have died of natural causes. The samples for DNA included teeth, bones and dry skin adhering to the skeletons.

DNA was extracted from these skeletons using ancient DNA techniques (aDNA). These samples were treated according to protocols established for aDNA analysis as this is defined as any DNA which has suffered autolytic or diagenetic processes (Herrmann \& Hummel, 1994). For this purpose guanidine thiocyanate and silica bead extraction methods were used (Boom et al., 1990) followed by a PCR reaction (Saiki et al., 1988). PCR amplification was performed with 6 sets of primers (Table 1), and under conditions set up separately for each reaction. The DNA extracted from bone, teeth and skin was amplified in a volume of $25 \mu \mathrm{l}$ through 40 cycles. The double-stranded PCR products were run on $1.5 \%$ low melting agarose gels to determine whether there was a successful amplification in the PCR reaction. The positive bands of these skeletal samples were cored directly from the gel using Pasteur pipettes followed by direct sequencing reaction using the Termo Sequenase kit (Amersham).

For the aDNA analyses, stringent precautions were taken to eliminate contamination. These included working under hoods that were sterilized between analyses with ultraviolet light, using different rooms for each stage of the procedure and disposable tips and sterile reagents. For each reaction, 2 sterile negative controls were used to check for contamination. In order to confirm the sequences, the complete analysis from 

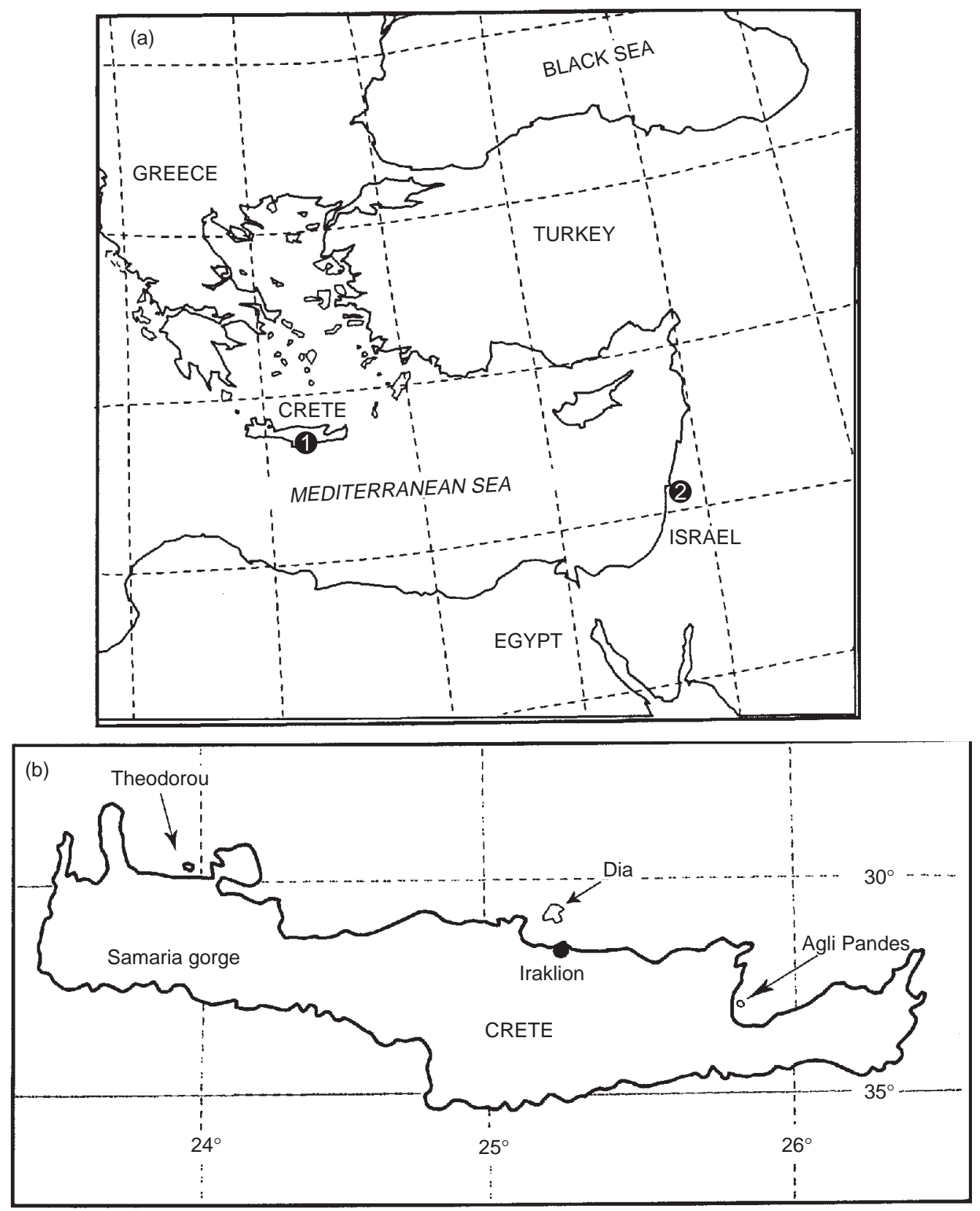

Fig. 2. (a) Locations from which samples of agrimi Capra aegagrus agrimi were taken: 1, Crete; 2, Hai-Bar Reserve, Mount Carmel, northern Israel; $(b)$ locations on Crete and adjacent islands where agrimi are found today.

extraction to sequencing was carried out at least twice independently for each sample. Thus, every amplified region has a minimum of 4 sequences, 2 with each primer. In order to analyse the data a consensus sequence was obtained for each set of primers using the ClustalX multiple sequence alignment software from the Molecular Biology Shortcuts website (Rodrigues \& Thompson, 1999).

Cytochrome $b$ sequences from the skeletal samples from Crete were first compared by geographic location (Fig. 3). They were then compared to the consensus sequence of the Hai-Bar Reserve agrimi, and finally to additional haplotypes for the same region of wild and domestic caprines from GenBank as given in Table 2, as well as the Baladi breed of goat (also known as the Syrian mountain goat; Hirsch, 1933; Epstein, 1971: 264), sequenced by us (Table 2). Phylogenetic analysis was carried out using the PAUP* version 4.0 (Swofford, 1993). The data were analysed using 3 methods: distance, maximum parsimony and maximum likelihood.

\section{RESULTS}

All five cytochrome $b$ (1050 bp) and D loop sequences (239 bp) of the living, Hai-Bar agrimi sample were found to be identical (Fig. 3). A consensus sequence was 
Table 1. Six sets of primers were used to amplify the cytochrome $b$ and D loop sequences. For the skeletal samples, three primers proved to be the most efficient: primers 86-92, G11-G12 and Gd1-Gd2. For agrimi no.21 from Theodorou Island, DNA was also amplified using another set of primers (117-116) while for agrimi no.14 from Samaria Gorge, the cytochrome $b$ had a positive reaction using the G9-G10 set of primers

\begin{tabular}{|c|c|c|c|c|c|c|c|}
\hline Primers & $\begin{array}{l}\text { Position } \\
\text { in gene }\end{array}$ & $\begin{array}{l}\text { Primer } \\
\text { name }\end{array}$ & & $\begin{array}{l}\text { Primer } \\
\text { location }\end{array}$ & Primer sequence & $\begin{array}{l}\text { Product } \\
\text { size (bp) }\end{array}$ & $\begin{array}{l}\text { Annealing } \\
\text { temperature } \\
\left({ }^{\circ} \mathrm{C}\right)\end{array}$ \\
\hline \multirow[t]{2}{*}{1} & 70 & 86 & Upper & Cytochrome $b$ & 5' CCATCCAACATATCAACATGA 3' & & \\
\hline & 214 & 92 & Lower & Cytochrome $b$ & 5' AATRCAGCCGTAGTTTACATC 3' & 165 & $46-48$ \\
\hline \multirow[t]{2}{*}{2} & 1009 & 116 & Lower & Cytochrome $b$ & 5' ACTGGCTGTCCTCCAATTCA 3' & & \\
\hline & 853 & 117 & Upper & Cytochrome $b$ & 5' CСТАACAAACTAGGAGGAGTC 3' & 176 & $46-48$ \\
\hline \multirow[t]{2}{*}{5} & 68 & G9 & Upper & Cytochrome $b$ & 5' ССССАТСАААСАТСТСАТСA 3' & & \\
\hline & 244 & G10 & Lower & Cytochrome $b$ & 5' ATACACGCAAACGGAGCA 3' & 196 & $50-52$ \\
\hline \multirow[t]{2}{*}{6} & 615 & G11 & Upper & Cytochrome $b$ & 5' CAACAACCCCACAGGAAT 3' & & \\
\hline & 831 & G12 & Lower & Cytochrome $b$ & $5^{\prime}$ ATACGCAATCCTACGA 3' & 236 & $50-52$ \\
\hline \multirow[t]{2}{*}{7} & 895 & 247 & Upper & Control region & 5' GGGGATGCTTGGACTCAGC 3' & & \\
\hline & 1051 & 248 & Lower & Control region & 5' TTAAAAATGGTGATAAATATTTTAGG 3' & 156 & $46-48$ \\
\hline \multirow[t]{2}{*}{8} & 907 & Gd1 & Upper & Control region & 5' GACTCAGCTATGGCCGTCT 3' & & \\
\hline & 1102 & $\mathrm{Gd} 2$ & Lower & Control region & 5' TATCTAGGAGGGAGCGTGTTT 3' & 216 & $50-52$ \\
\hline
\end{tabular}

Table 2. List of specimens, GenBank Numbers and their sources that were used in this study

\begin{tabular}{|c|c|c|c|c|c|}
\hline Code Used & $\begin{array}{l}\text { GenBank } \\
\text { no. }\end{array}$ & $\begin{array}{l}\text { No. of } \\
\text { specimens }\end{array}$ & Gene & Reference & Goat breed and geographical location \\
\hline C. hircus 1 & AB004070 & 1 & Cytochrome $b$ & Takada et al., 1997 & $\begin{array}{l}\text { Japanese native, Saanen, small meat type } \\
\text { goat, National Livestock Breeding Center, } \\
\text { Nagano Station, Japan }\end{array}$ \\
\hline C. hircus 2 & AB004071 & 1 & Cytochrome $b$ & Takada et al., 1997 & $\begin{array}{l}\text { West African Dwarf, small meat type goat, } \\
\text { National Livestock Breeding Center, } \\
\text { Nagano Station, Japan }\end{array}$ \\
\hline C. hircus 3 & AB004072 & 1 & Cytochrome $b$ & Takada et al., 1997 & $\begin{array}{l}\text { Korean native, small meat goat, introduced } \\
\text { from Korea }\end{array}$ \\
\hline C. hircus 4 & AB004073 & 1 & Cytochrome $b$ & Takada et al., 1997 & $\begin{array}{l}\text { Pakistan lop-eared goats, Miyazaki Phoenix } \\
\text { Zoo, Miyazaki, Japan }\end{array}$ \\
\hline C. hircus 5 & AB004074 & 1 & Cytochrome $b$ & Takada et al., 1997 & $\begin{array}{l}\text { Japanese native, Shiba, small meat goat, } \\
\text { National Livestock Breeding Center, } \\
\text { Nagano Station, Japan }\end{array}$ \\
\hline C. hircus 6 & AB004075 & 1 & Cytochrome $b$ & Takada et al., 1997 & $\begin{array}{l}\text { Japanese native, Tokara, small meat goat } \\
\text { National Livestock Breeding Center, } \\
\text { Nagano Station, Japan }\end{array}$ \\
\hline C. hircus 7 & D84201 & 1 & Cytochrome $b$ & Arai et al., 1997 & Unknown \\
\hline C. hircus 8 & X56289 & 1 & Cytochrome $b$ & $\begin{array}{l}\text { Irwin, Kocher \& } \\
\text { Wilson, } 1991\end{array}$ & $\begin{array}{l}\text { DNA from D. E. Dobson, Boston } \\
\text { University School of Medicine, USA }\end{array}$ \\
\hline Baladi & AF217254 & 5 & Cytochrome $b$ & $\begin{array}{l}\text { Kahila Bar-Gal et al., } \\
\qquad 1999^{\mathrm{a}}\end{array}$ & $\begin{array}{l}\text { Blood, Baladi breed from a herd kept at } \\
\text { Matat, Galilee, North Israel }\end{array}$ \\
\hline C. aegagrus 1 & AB004069 & 1 & Cytochrome $b$ & Takada et al., 1997 & Gumma Safari Park, Tomiok, Japan \\
\hline C. aegagrus 2 & D84204 & 1 & Cytochrome $b$ & Arai et al., 1997 & Unknown Captive \\
\hline C. aegagrus 3 & AF034739 & 1 & Cytochrome $b$ & $\begin{array}{l}\text { Hassanin, Pasquet \& } \\
\text { Vigne, } 1998\end{array}$ & $\begin{array}{l}\text { Blood, from J. L. Berthier, Menagerie du } \\
\text { Jardin des Plantes, Paris, France }\end{array}$ \\
\hline C. aegagrus 4 & AJ231408 & 1 & Cytochrome $b$ & Manceau et al., 1999 & $\begin{array}{l}\text { Bone, from St Petersburg Museum; } \\
\text { specimen origin Turkmenistan }\end{array}$ \\
\hline C. aegagrus 5 & AJ231409 & 1 & Cytochrome $b$ & Manceau et al., 1999 & $\begin{array}{l}\text { Bone, from St Petersburg Museum; } \\
\text { specimen origin Iran }\end{array}$ \\
\hline C. falconeri 1 & AF034739 & 1 & Cytochrome $b$ & Hassanin et al., 1998 & $\begin{array}{l}\text { Bone, Laboratoire de Mammiferes and } \\
\text { Oiseaux, MNHN, Paris, France }\end{array}$ \\
\hline C. falconeri 2 & D84202 & 1 & Cytochrome $b$ & al., 1997 & Unknown \\
\hline C. falconeri 3 & $\mathrm{AJ} 231415$ & 3 & Cytochrome $b$ & Manceau et al., 1999 & Bone, from the field \\
\hline C. falconeri 4 & AJ231414 & 2 & Cytochrome $b$ & Manceau et al., 1999 & Bone, from the field \\
\hline C. falconeri 5 & $\mathrm{AJ} 231413$ & 1 & Cytochrome $b$ & Manceau et al., 1999 & Bone, from St Petersburg Museum \\
\hline Agrimi & AF217255 & 5 & Cytochrome $b$ & $\begin{array}{l}\text { Kahila Bar-Gal et al., } \\
1999^{\text {a }}\end{array}$ & $\begin{array}{l}\text { Blood, captive herd kept in Hai-Bar Reserve, } \\
\text { Mt Carmel, Israel }\end{array}$ \\
\hline
\end{tabular}

\footnotetext{
${ }^{\mathrm{a}}$ Date of GenBank submission.
} 


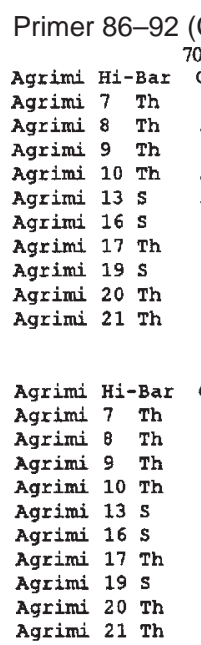

(Cytochrome b)

Agrimi Hi-Bar CCATCAAACATCTCATCATGATGAAACTTTGGATCCCTCCTAGGAATTTGCCTAATCTTACAAATCCTGACAGGCCTATTCCTAGCAATACACTATACATCCGACACAATAACAG

Agrimi 7 Th

Agrinis 9 Th

Agrimi 10 Th

Agrimi 13 s

Agrimi $16 \mathrm{~s}$

Agrimi $19 \mathrm{~S}$

Agrimi 20 Th

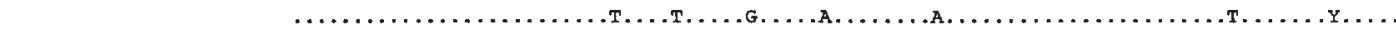

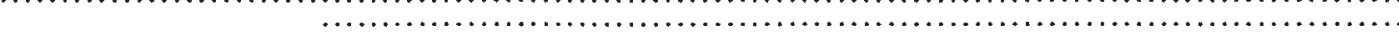

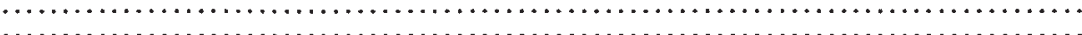
(.

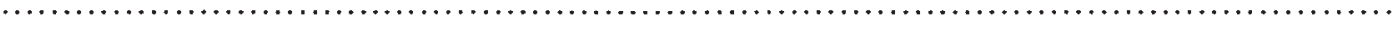

223

CATITTCCTCTGTAACTCACATITGTCGAGATGTAAATTATGGCTGATCA

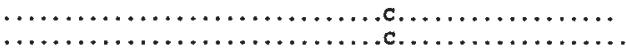

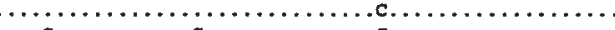

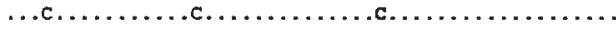

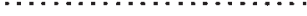

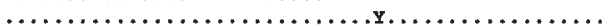

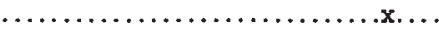

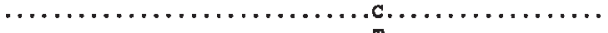

Primer G11-G12 (Cytochrome b)

Agrimi Hi-Bar

Agrimi 7 Th

Agrimi 8 Th

Agrimi 8 Th

Agrini g Th

Agrimi $10 \mathrm{Th}$

Agrimi $13 \mathrm{~s}$

Agrimi $16 \mathrm{~s}$

Agrimi 17 Th

Agrimi $21 \mathrm{Th}$

Agrimi Hi-Bar

Agrimi 7 Th

Agrimi \& Th

Agrimi 9 Th

Agrimi 10 Th

Agrimi 13 s

Agrimi $16 \mathrm{~S}$

Agrimi $17 \mathrm{Th}$

Agrimi 21 Th

AACAACCCCACAGGATTCCATCAGACACAGATAAAATCCCATTTCACCCTTACTACACCATTAAAGATATCTTAGGCGCCATGCTACTAATTCTTGTTCTAATATTACTAGTACTAT

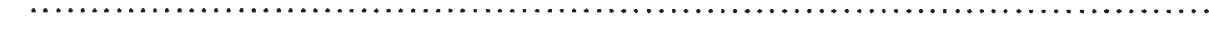

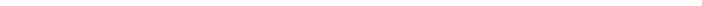

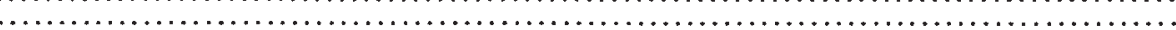
(.......

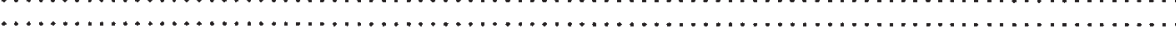

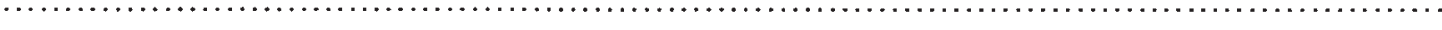

TCACACCCGACCTACTCGGAGACCCAGACAACTATATCCCAGCAAATCCACTCAATACACCCCCTCACATTAAACCTGAGTGGTATTTCCTATTTGCATACGCAATCCTACGATCAAT

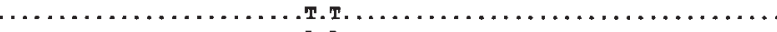

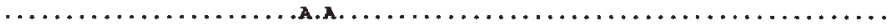

.

(1)

.

.

......T. T.

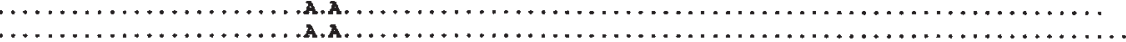

Primer Gd1-Gd2 (D loop)

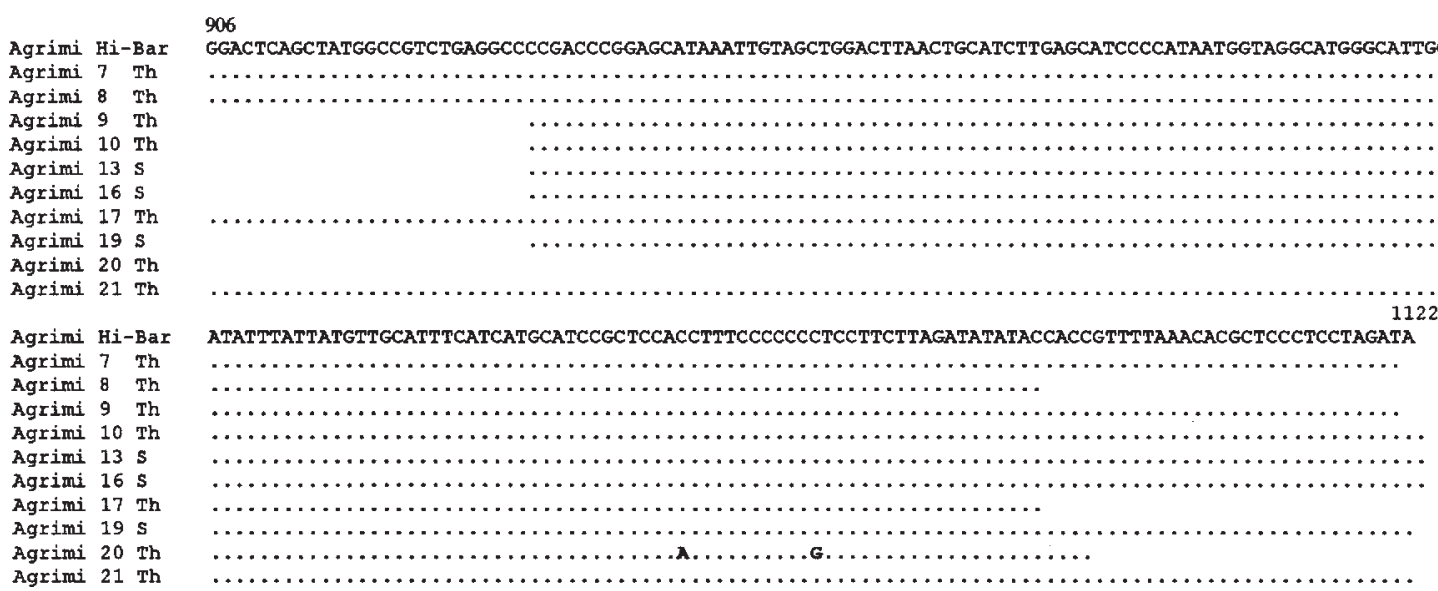

Fig. 3. Comparison of agrimi Capra aegagrus cretica cytochrome $b$ and D loop sequences. First three columns, identity number of the individual specimen and its location of origin; Hi-Bar, Hai-Bar Reserve, Israel; Th, Theodorou Island, Crete; S, Samaria Gorge, Crete. The Hai-Bar sample represents a consensus sequence comprising 10 identical haplotypes. Following columns: dots, identical sequence; $\mathrm{X}$, unknown nucleotide; - , deletion; C, cytosine; T, thymine; A, adenine; G, guanine; Y, cytosine or thymine.

determined for each region for this population (cytochrome $b$, GenBank number AF217255; D loop, GenBank number AF217259).

For 11 of the $12(92 \%)$ agrimi skeletal samples, DNA could be amplified for two regions of the cytochrome $b$ and one region of the D loop; in eight samples $(66.7 \%)$ DNA was amplified from three different areas; and for four samples only two fragments could be amplified. For the two sets of cytochrome $b$ primers that were amplified (Table 1), a maximum of 362 bp were 


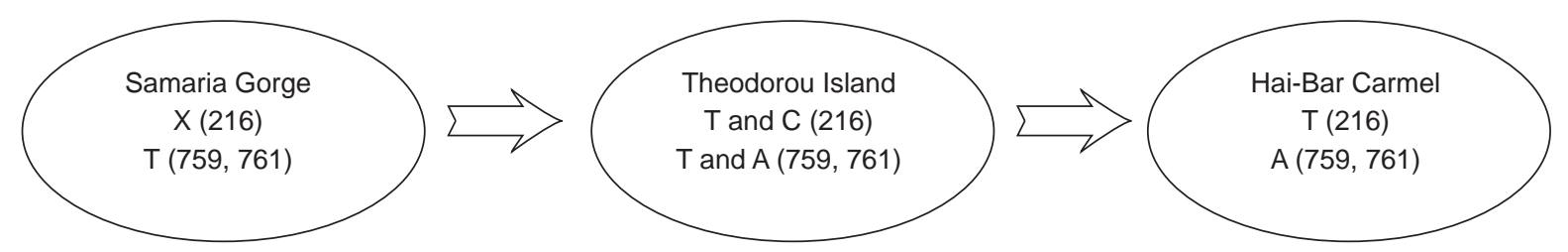

Fig. 4. Diagram showing the relationship between populations of agrimi Capra aegagrus cretica and polymorphic sites on two regions of the cytochrome $b$ gene. Samaria is the parent population from which the Theodorou Island population is derived. The Hai-Bar agrimi are derived in turn from the Theodorou Island herd. All Hai-Bar agrimi have an identical sequence; two sequences from Samaria Gorge differ from the Hai-Bar agrimi in having hymine in position 759 and 761 . The sequences from Theodorou Island are variable with three polymorphic sites at positions 216, 759,761. At position 216, four sequences have cytosine and one sequence has hymine; at position 759,761 four sequences have adenine and two sequences have thymine.

sequenced, which is about one-third of the gene (which in total comprises $1100 \mathrm{bp}$ ).

Comparison of the two main regions of the cytochrome $b$ that were amplified showed the presence of a polymorphism in the three agrimi populations; Hai-Bar, Samaria and Theodorou Island (Fig. 4). The sequences obtained using primer G86-92, indicate that nucleotide sequences in four specimens from Theodorou (specimens nos 7, 8, 20 and 21) varied at position 216 (Fig. 3). Three Theodorou specimens (nos 7, 8 and 20) exhibited a transition of thymine to cytosine, which did not change the amino acids, and is indicative of a polymorphism on the island. This polymorphism indicates that a separation of 54 years, this being the date when the last pair was introduced to the island from Samaria, may have been long enough to establish minor genetic differences between populations. However, larger samples from both locations are needed to verify this. Unfortunately, for this region of the cytochrome $b$, the sequences of the Samaria agrimi are missing, and as such cannot be compared. However, comparison of this cytochrome $b$ region with other Capra species indicates that all the published domestic goats, wild goats and C. falconeri have a thymine in position 216, like the agrimi from the Hai-Bar reserve. For this region of the cytochrome $b$, the sequence obtained for agrimi no. 9 was aberrant and so suspected of being an artefact, and was not included in the phylogenetic analysis using this region.

Two groups of agrimi were recognized based on sequences at the second region using primer G11-12 (Fig. 3). The first group has nucleotide thymine in positions 759 and 761 and comprises specimens from Theodorou Island (nos 7 and 9) and Samaria Gorge (nos 13 and 16). The second group, comprising animals from the Hai-Bar reserve and Theodorou Island, has adenine in positions 759 and 761 (specimen nos 8, 10, 17 and 21). The substitutions are two transversions in the second and third codon, which caused one amino acid change (Asp-Val).

The results illustrated in Figs $3 \& 4$, demonstrate that the Hai-Bar reserve consensus sequence is identical to that of one goat from Theodorou (no. 21). This specimen represents a variant of the sequence occurring on the island that was present in the six founder animals that established the Hai-Bar herd. Based on these data, the Theodorou Island population seems to be more polymorphic than their parent population in western Crete and their daughter population in Israel.

For the D loop (primer Gd1-Gd2), 16 of the 17 agrimi specimens had identical sequences (Fig. 3). The one exception, specimen no. 20 from Theodorou, differs in two substitutions (a transition and a transversion) and one deletion. The high degree of homology of the D loop sequences (a non-coding region), suggests that we are dealing with a relatively conserved region of the D loop rather than a hypervariable one.

The three agrimi populations studied here closely resemble each other. In the cytochrome $b$ sequence there is a similarity of $99.3 \%$ among all the sampled individuals with additions of three polymorphic sites at positions 216, 759 and 761 (Fig. 4). This divergence rate is similar to that found among breeds of domestic goats $(0.6-0.84 \%)$.

In order to determine the genetic affinity of the agrimi to domestic and wild goats, three methods of phylogenetic analysis were used. In these analyses the sequences were compared to published sequences of wild and domestic goats from GenBank (Table 2). All three methods of analysis (distance, maximum parsimony and maximum likelihood) and all three sequenced regions, showed the same pattern of relationship with the agrimi sequences closely related to the different breeds of domestic goats, but differing from the wild goats, C. falconeri and two C. aegagrus specimens.

As many of the goat cytochrome $b$ sequences in GenBank are limited to short sequences, the region that incorporates the greatest number of sequences (i.e. the region amplified with primers 86-92) was used. The resulting phylogeny (Fig. 5), shows that the cytochrome $b$ sequences of the agrimi (agrimi nos 1,2, 3 and 4) all clade with the domestic goats and lie on a different branch to two of the bezoar goats (C. aegagrus nos 3 and 4) and the five samples of $C$. falconeri. Moreover, the consensus sequence of the agrimi goats from the Hai-Bar and agrimi no. 21 from Theodorou island, are identical to the Baladi goat; an indigenous breed of domestic goat from the southern Levant (Hirsch, 1933; Epstein, 1971). 


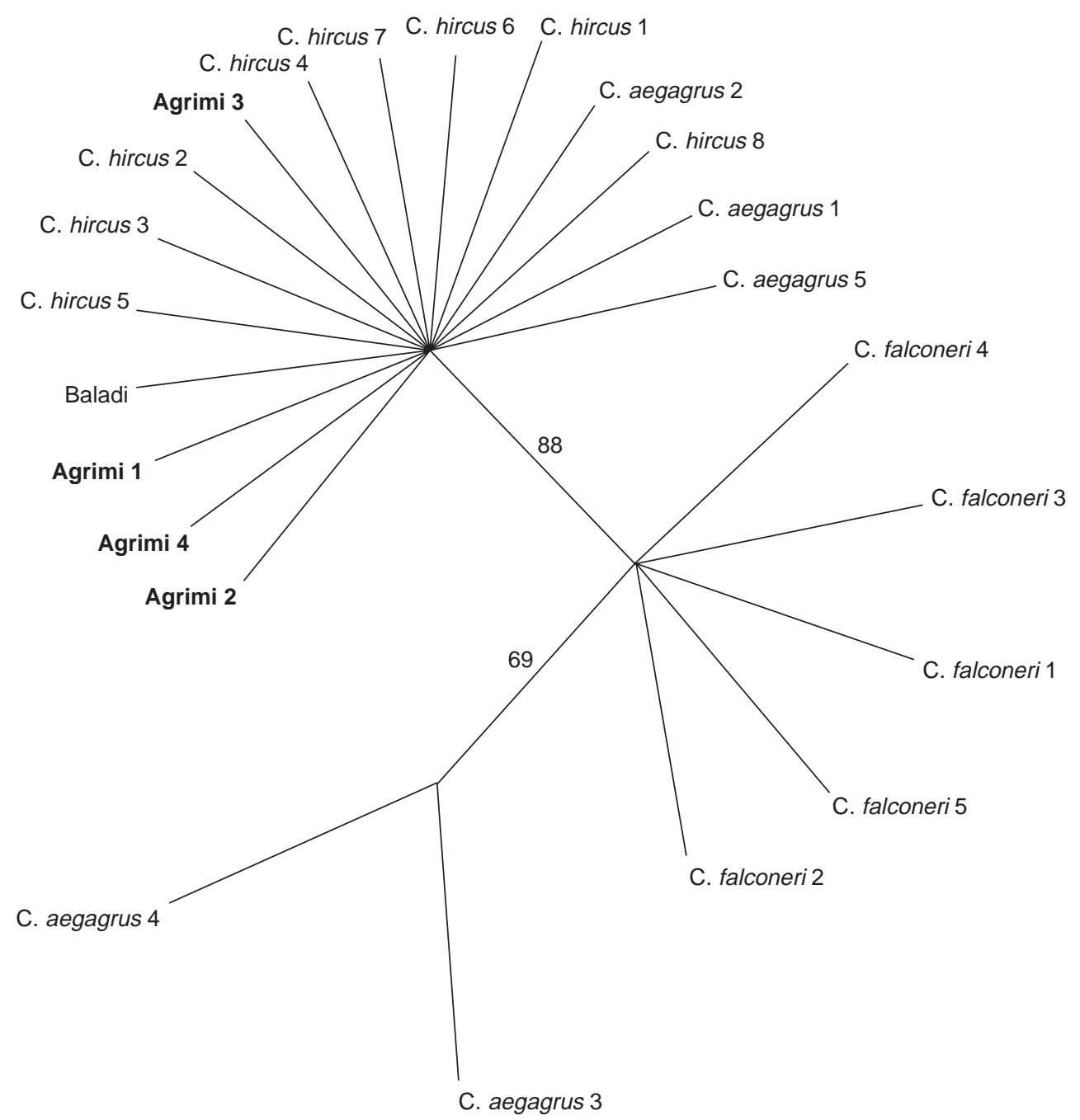

Fig. 5. Phylogenetic analysis of agrimi sequences using primer G86-92 of cytochrome $b$ (based on maximum parsimony analysis heuristic search). The bootstrap values (obtained after 100 replicates) are indicated on the internal branches. Data on wild and domestic goats are taken from samples in GenBank as described in Table 2. The agrimi sequences shown in this clade are grouped according to the length of their cytochrome $b$ sequences (as given in Fig 3): agrimi 1, Hai-Bar consensus sequence and agrimi no. 21 from Theodorou Island; agrimi 2, agrimi nos 10, 13 \& 17; agrimi 3, agrimi nos $7 \& 19$; agrimi 4, agrimi nos 8 , 16 \& 20.

\section{DISCUSSION}

As shown in Fig. 5, three of the published bezoar sequences ( $C$. aegagrus nos 1, 2 and 5), clade with the domestic goats. The first two sequences are derived from zoo specimens and it is not inconceivable that they represent hybrids or even agrimi. The third specimen (C. aegagrus no. 5) is derived from a museum sample originating in Iran (Table 2). Recent studies on the systematics of Capra (Manceau et al., 1999: fig. 2) have shown a similar dichotomy for sequences of the bezoar goat, with the same $C$. aegagrus specimen from Iran grouping with domestic goats and agrimi, while another two $C$. aegagrus specimens from Turkmenistan (our C. aegagrus nos 3 and 4) cluster on a different clade.

Thus, the two sequences of $C$. aegagrus (nos 3 and 4) that cluster together, are perhaps the only specimens that represent true $C$. aegagrus aegagrus. These sequences group together on a distinct branch and lie furthest from the domestic goats and closest to the other wild goat specimens of C. falconeri. As shown in Fig. 5, the bootstrap values, after 100 replicates based on maximum parsimony analysis heuristic search, provide strong support for this separation.

However, the genetic variation exhibited by the C. aegagrus specimens is problematic and raises an important issue concerning sampling procedures used during DNA research. Two of the $C$. aegagrus specimens (nos 1 and 2) that clade with the domestic goats, are derived from zoo specimens and not from free-living wild animals (Table 2). However similarly, the two bezoar specimens that are outliers (C. aegagrus nos 3 
and 4) are derived from a museum collection and the Paris zoo, respectively (Table 2). The results obtained from the genetic analyses, emphasize the problems of using samples taken from captive animals and museum collections for genetic analyses. The source of these specimens is often unknown, frequently no sub-specific determination is given and their identification is based only on morphological characteristics so that there is always a possibility that they may be hybrids, or even agrimi. Indeed, it cannot be discounted that some hybridization with domestic breeds has taken place in the bezoar goat, especially as in most parts of the world C. aegagrus survives only in relict populations (Uerpmann, 1987). Alternatively, Manceau et al. (1999) may be correct in suggesting that the ancestral populations of wild goats displayed broad heterogeneity and that specifically, those from the Fertile Crescent gave rise to domestic goats. This may account for the resemblance between the $C$. aegagrus specimen from Iran and C. hircus specimens.

Thus in the absence of samples from free-living animals of known origin, museum and zoo specimens have to suffice, but as noted here, are problematic. Although we have obtained sequences of goats from ancient DNA samples (Kahila Bar-Gal et al., in press), these data are of limited comparative use with modern samples because of specific problems relating to aDNA (e.g. short sequences as well as the limited number of sequences that can be obtained). Results obtained to date do, however, distinguish clearly between wild and domestic goats (Kahila Bar-Gal et al., in press).

On the one hand, the close relationship of all 17 agrimi sequences studied here to those obtained from of a variety of domestic goat breeds (Capra hircus) and the separation between them and the sequences of $C$. aegagrus nos 3 and 4 and $C$. falconeri on the other hand, supports the hypothesis that the agrimi $(C$. aegagrus cretica) is not a sub-species of the wild bezoar goat but rather a feral animal. Even though data are based on short sequences, Manceau et al. (1999) obtained the same results, and like us concluded that the agrimi is a feral goat.

Note that the agrimi sequences are identical to those of the Baladi goat, a breed that is indigenous to the Levant. This close relationship may be a reflection of the geographic origin of early domestic goats including those initially colonizing Crete. Indeed, the genetic findings corroborate recent archaeozoloogical hypotheses on the origins of the domestic goat, which suggest a Levantine origin such as the Jordan Valley and its periphery (Horwitz et al., 1999; Peters et al., 1999) or the region adjacent to the mountains of Lebanon or the Anti-Lebanon (Wasse, 2001). If these hypotheses are correct, then the indigenous Baladi goat breed may represent a direct descendent of these early domestic forms. Our genetic data support such a conjecture, as the timing of the initial importation of goats to Crete (c. 7000 uncal. BC) would have taken place relatively close to the hypothesized onset of their domestication in the Levant, c. 8000 uncal. BC (Peters et al., 1999; Wasse,
2001) or even slightly later, $c .7500$ uncal. BC (Horwitz et al., 1999).

Despite the physical and behavioural resemblance of the agrimi to the wild bezoar goat (Fig. 1), the molecular data do not support the hypothesis that it is a true subspecies or even a geographic variant of Capra aegagrus aegagrus. The agrimi is a feral animal derived from a primitive domestic goat which, following its importation to Crete in the Aceramic Neolithic period, returned to the wild. The apparent contradiction between the morphology and the genetic composition of the agrimi illustrates the limitations of classical taxonomy. As demonstrated by Randi et al. (1990) for goats on the island of Montecristo off Italy, when domestic animals become feral, selective pressures may result in a reversion to a 'wild' phenotype.

In the light of these findings, it is suggested that the taxonomic classification of agrimi should be revised. Moreover, this study has illustrated the importance of applying DNA analysis to taxonomic disputes. Finally, the high correlation found between results obtained using conventional analyses of live animals and those using aDNA techniques on skeletonized remains, demonstrates the validity of the latter approach.

\section{Acknowledgements}

Part of this research was funded by a grant (PICS 406) from the Centre National de la Recherche Scientifique of France (to P. Ducos and E. Tchernov). Our special thanks to the Ministry of Agriculture, General Office of Forests, Athens, Greece and The Director of Forests, Chania, Crete for permission to sample the Samaria Gorge and Theodorou Island agrimi, as well as invaluable logistical assistance that facilitated visits to both locations. We also wish to thank the Israel Nature Reserves Authority and the Director of the Hai-Bar Carmel and staff for their permission as well as invaluable assistance rendered during sampling of the captive herd of agrimi held in the reserve.

\section{REFERENCES}

Arai, K., Munechika, I., Ito, I., Kikkawa, A., Nakamura, K., Kanazawa, T. \& Kosugiyama, M. (1997). Phylogenetic relationship of Caprini estimated by cytochrome $b$ gene sequence analysis. Anim. Soc. Technol. 68: 148.

Boom, R., Sol, C. J. A., Salimans, M. M. M., Jansen, C. L., Wertheim-van Dillen, P. M. E. \& van der Noordaa, J. (1990). Rapid and simple method for purification of nucleic acids. $J$. Clin. Microevol. 28: 495-503.

Ciani, F. \& Masseti, M. (1991). Considerazioni sull'origine della popolazione ircina dell'isola di Montecristo, nel mar Tirreno settentrionale. Elementi per un confronto cronologico-culturale con l'antica diffusione artificiale dell'egagro (Capra aegagrus Erxleben, 1777) nelle isole del Mediterraneo Orientale. Atti Conv. Genet. Conserv. fauna Suppl. Ric. Biol. Selvaggina 18: 123-133.

Corbet, G. B. (1978). The mammals of the Palaearctic region: a taxonomic review. London: British Museum Natural History. 
Epstein, H. (1971). The origin of the domestic animals of Africa II. New York: Africana Publishing.

Filon, D., Rund, D., Rachmilewitz, E. A. \&. Oppenheim, A. (1992). Advances in the prenatal diagnosis of beta-thalassemia in Israel. In Genetic diversity among Jews: 358-364. BonneTamir, B. \& Adam, A. (Eds). New York: Oxford University Press.

Groves, C. P. (1989). Feral mammals of the Mediterranean islands: documents of early domestication. In The walking larder: 46-58. Clutton-Brock, J. (Ed.). London: Unwin Hyman.

Harris, D. R. (1960-61). The distribution and ancestry of the domestic goat. Proc. Linn. Soc. Lond. 173: 79-91.

Harrison, D. L. \& Bates, P. J. J. (1991). The mammals of Arabia. 2nd edn. Harrison Zoological Museum Publication.

Hassanin, A., Pasquet, E. \& Vigne, J.-D. (1998). Molecular systematics of the subfamily Caprinae (artiodactyla, Bovidae) as determined from cytochrome $b$ sequences. J. Mamm. Evol. 5: 217-239.

Herrmann, B. \& Hummel, S. (1994). Introduction. In Ancient DNA: 1-12. Herrmann, B. \& Hummel, S. (Eds). New York: Springer-Verlag.

Hirsch, S. (1933). Sheep and goats in Palestine. Tel Aviv: The Palestine Economic Society.

Horwitz, L. K., Tchernov, E., Ducos, P., Becker, C., von den Driesch, A., Martin, L. \& Garrard, A. (1999). Animal domestication in the southern Levant. Paleorient 25(2): 63-80.

Husband, T. P. (1977). Ecology and behaviour of the Cretan agrimi following population reduction. $\mathrm{PhD}$ dissertation. Michigan: Ann Arbor Microfilms.

Husband, T. P. \& Davis, P. B. (1984). Ecology and behaviour of the Cretan agrimi. Can. J. Zool. 62: 411-420.

Irwin, D. M., Kocher, T. D. \& Wilson, A. C. (1991). Evolution of the cytochrome $b$ gene of mammals. J. Mol. Evol. 32: 128-144.

Jarman, M. R. (1996). Human influence in the development of the Cretan mammalian fauna. In Pleistocene and Holocene fauna of Crete and its first settlers: 211-230. Reese, D. S. (Ed.). Madison, WI: Prehistory Press.

Kahila Bar-Gal, G., Khalaily, H., Marder, O., Ducos, P. \& Horwitz, L. K. (In press). Ancient DNA evidence for the transition from wild to domestic status in Neolithic goats: a case study from the site of Abu Gosh, Israel. Ancient Biomolecules.

Lax, E. \& Strasser, T. F. (1992). Early Holocene extinctions on Crete: the search for a cause. J. Medit. Archaeol. 5(2): 203-224.

Manceau, V., Despres, L., Bouvet, J. \& Taberlet, P. (1999). Systematics of the genus Capra inferred from mitochondrial DNA sequence data. Mol. Phylogenet. Evol. 13: 504-510.

Mason, I. L. (1984). Goats. In Evolution of domesticated animals: 85-99. Mason, I. L. (Ed.). London: Longman.

Nicholson, M. C. \& Husband, T. P. (1992). Diurnal behavior of the agrimi, Capra aegagrus. J. Mammal. 73: 135-142.

Nobis, G. (1998). Studien an tierresten aus den archaologischen grabungen Poros bei Iraklion und Eleftherna bei Arkadhi ein beitrag zur antinken wild-und haustierfauna Kretas. In Man and the animal world: 409-433. Anreiter, P., Bartosiewicz, L., Jerem, E. \& Meid, W. (Eds). Budapest: Archaeolingua.

Papageorgiou, M. (1974). Population energy relationships of the agrimi (Capra aegagrus cretica) on Theodorou Island, Greece. PhD dissertation. Michigan: Ann Arbor Microfilms.

Peters, J., Helmer, D., von den Driesch, A. and Sana Segui, M. (1999). Early animal husbandry in the northern Levant. Paleorient 25: 27-48.

Porter, R. (1996). The Cretan wild goat (Capra aegagrus cretica) and the 'Theran antelopes'. In Pleistocene and Holocene fauna of Crete and its first settlers: 295-314. Reese, D. S. (Ed.). Madison, WI: Prehistory Press.

Randi, R., Tosi, G., Toso, S., Lorenzini, R. \& Fusco. G. (1990). Genetic variability and conservation problems in Alpine ibex, domestic and feral goat populations (genus Capra). Z. Saugetierkd. 55: 413-420.

Rodrigues, P. \& Thompson, J. (1999). Hyperlink: http://www.Mbshortcuts.com/www.mbshortcuts.com.

Saiki, R. D., Geelfand, D. H., Stoffel, S., Scharf, S. J., Higuchi, R., Horn, G. T., Mullis, K. B. \& Erlich, H. A. (1988). Primerdirected enzymatic amplification of DNA with thermostable polymerase. Science 239: 487-491.

Schultze-Westrum, T. (1963). Die wildziegen der agaischen Inseln. Saeugertierkd. Mitt. 11: 145-182.

Swofford, D. L. (1993). PAUP: phylogenetic analysis using parsimony. Version 3. 1. 1. Champaign, IL: Illinois Natural History Survey.

Takada, T., Kikkawa, Y., Yonekawa, H., Kawakami, S. \& Amano. T. (1997). Bezoar (Capra aegagrus) is a matriarchal candidate for ancestor of domestic goat (Capra hircus): evidence from the mitochondrial diversity. Biochem. Genet. 35: 315-326.

Uerpmann, H-P. (1987). The ancient distribution of ungulate mammals in the Middle East. Beihefte zum Tubinger Atlas des vorderen Orients. Reihe, A (Ed.). No. 27. Wiesbaden: L. Reichert.

Valdez, R. (1990). Capra. In Grzimek's encylopedia of mammals $\mathbf{5}$ : 535-537. Grzimek, B. (Ed.). New York: McGraw Hill.

Vanschoonwinkel, J. (1996). Les animaux dans L'Art Minoen. In Pleistocene and Holocene fauna of Crete and its first settlers: 351-412. Reese, D. S. (Ed.). Madison, WI: Prehistory Press.

Walker, E. P. (1983). Artiodactyla; Bovidae; genus Capra Linnaeus, 1758. In Walkers mammals of the World II: 1298-1300. 4th edn. Baltimore: Johns Hopkins University Press.

Wasse, A. (2001). The wild goats of Lebanon: evidence for early domestication? Levant 33: 21-33.

Wilkens, B. (1996). The fauna from Italian excavations on Crete. In Pleistocene and Holocene fauna of Crete and its first settlers: 241-262. Reese, D. S. (Ed.). Madison, WI: Prehistory Press.

Yoffe, A. (1980). Breeding endangered species in Israel. Int. Zoo Yearb. 20: 127-137.

Zimmerman, von K., Wettstein, O. V., Siewert, H. \& Pohle, H. (1942-49). I. Die wildsauger von Kreta. Z. Saugetierkd. 17: 1-72. 